\title{
The Relationship Between Segment-Level Manipulations And Audit Fees
}

David Hurtt, Baylor University, USA

Bradley E. Lail, Baylor University, USA

Jason MacGregor, Baylor University, USA

\begin{abstract}
We examine the auditor's sensitivity to manipulative financial reporting by investigating the relation between audit fees and segment-level manipulations. Segment reporting provides an interesting setting to examine auditor risk assessments because of the discretion afforded to management under existing regulations. Segment manipulations, a form of classification smoothing, are not in violation of accounting standards; nevertheless, these manipulations violate the spirit of faithful representation by distorting the performance of a subset of the reporting unit at the expense of (or to the benefit) of another subset. Because disaggregated information is used by analysts and investors in bottom-up forecasting, these distortions can influence firm value even though they do not affect bottom-line net income. Our measure of classification smoothing measures cost shifting between core operating segments and non-core segments to proxy for segment manipulation. We find that audit fees, a proxy for the auditor's risk assessment, have a positive association with segment-level manipulations. Subsequent analyses suggest that higher audit fees are also due to the additional effort exerted in the presence of segment-level manipulations. Further, auditors appear justified in charging higher fees to clients that engage in segment manipulations as we document evidence of a positive association between restatements and segment-level manipulations. Collectively, these results suggest that auditors are aware of the risk associated with companies that engage in segment-level manipulations and auditors respond appropriately by charging higher fees and doing additional work.
\end{abstract}

Keywords: Classification Shifting; Segment Reporting; Segment-level Manipulations; Audit Fees

\section{INTRODUCTION}

$\mathscr{I}$ $\mathrm{n}$ the Sarbanes-Oxley era, auditors are under regulatory pressure to design audits that employ a 'riskbased' approach. For instance, in 2010 the PCAOB issued a suite of risk-assessment standards to increase auditor sensitivity to the risks of material misstatements. These standards call for auditors to respond to company-specific factors that affect management's judgments in determining accounting estimates as well as factors perceived to influence managerial incentives. ${ }^{1}$ In this paper, we examine the auditor's sensitivity towards the manipulation of segment-level results.

Segment manipulations are a form of classification smoothing where a reporting segment's performance is distorted by allocating costs to (or from) other segments. These manipulations can conform to accounting standards but may nevertheless be indicative of management adopting an aggressive approach to financial reporting. Further, because segment reporting is used by financial statement users in constructing bottom-up forecasts of future growth rates, manipulation of segment results is misleading even when the consolidated financial performance is unaffected. We specifically consider how audit fees vary with the level of segment reporting manipulations. To the degree that

\footnotetext{
${ }^{1}$ The eight new auditing standards are: Audit Risk (AS. No. 8); Audit Planning (9); Supervision of the Audit (10); Consideration of Materiality in Planning and Performing an Audit (11); Identifying and Assessing Risks of Material Misstatement (12); The Auditor's Responses to the Risks of Material Misstatement (13); Evaluating Audit Results (14); and Audit Evidence (15).
} 
auditors price segment-level manipulations, we gain insight into auditors' attentiveness to the potential risk of this influential financial statement disclosure.

While previous research has established that audit fees vary with the level of accrual management (Gul et al. 2003; Abbott et al. 2006; Antle and Gordon 2006; Choi et al. 2010; Schelleman and Knechel 2010), researchers have yet to consider whether audit fees vary with classification management techniques, including segment-level manipulations. Broadly, classification management involves the re-classification of financial statement items for the purpose of enhancing certain performance measures, such as core earnings, without changing bottom-line net income. $^{2}$ Account manipulation to improve the perception of the firm has been extensively discussed and researched. ${ }^{3}$ Classification smoothing was the focus of McVay's (2006) research which showed that managers will shift expenses out of operating income to more transitory "special items." While classification management may conform to reporting standards, it may nevertheless reveal evidence of an aggressive reporting culture set by the tone of upper management. The auditor may assess such a tone as a significant risk factor.

Segment-level classification management is the manipulation of how consolidated performance is disaggregated in the notes to the financial statements. Current segment reporting requirements grant managers significant discretion which could lead to the horizontal shifting of income and expenses between segments (Givoly et al. 1999; Lail et al. 2013). ${ }^{4}$ For example, managers have the discretion to shift expenses from core (or operating) segments to non-core segments (or vice-versa) as long as such a shift complies with the chosen segment definitions and measure of performance. ${ }^{5}$ Manipulating segment classification allows managers to "window dress" financial statements by improving reported results in favored industrial sectors or geographic regions. Segment manipulations can be accomplished either by shifting expenses from one division to another or by favorably grouping divisions when constructing reported segments. While this manipulation does not alter consolidated net income, it can enhance (reduce) the reported performance of some key segments to the detriment (advantage) of others. Research has shown that segment results are important to many financial statements users including security analysts, investors, regulators, and academics (e.g., Kinney 1971; Collins 1976; Baldwin 1984; Thomas 2000; Berger and Hann 2003; Ettredge et al. 2005). Because analysts and investors weigh core operating performance heavily when forecasting earnings (Bradshaw and Sloan 2002; Bhattacharya et al. 2004; Gu and Chen 2004), managers have incentives to manipulate core operating profitability. Alternatively, managers may have incentives to disguise high segment performance to forestall competition.

Segment-level reporting manipulations present a unique audit research setting as they may provide a more useful proxy for managerial aggressiveness than abnormal accruals used in traditional earnings management studies. Because auditors are expected to constrain artificially inflated accruals, the reported level of accruals represents the joint product of auditor and client efforts (Choi et al. 2010). In contrast, an auditor's primary task as it relates to segment reporting is verifying consistency between internal and external definitions of segments. Thus, the auditor is not charged to restrain managerial opportunism in this area. This suggests that segment-level manipulation provides accounting researchers a better measure of unconstrained managerial aggressiveness or "tone at the top" than abnormal accruals.

To investigate whether auditors are sensitive to the risk of segment manipulation, we examine the relation between audit fees and unexpected segment performance. Audit fees are a proxy for the auditor's risk assessment and auditor effort (Hay et al. 2006). A positive association would suggest auditors are aware of segment-level manipulations and interpret such behavior as a meaningful risk factor. Alternatively, a negative association would be indicative of auditors exerting lower than expected effort to detect management's segment-level manipulations. If

\footnotetext{
${ }^{2}$ Core earnings is operating income before depreciation and special items.

${ }^{3}$ See Stolowy and Breton (2004) for a review of the literature.

${ }^{4}$ The current reporting standard for segment reporting originated with Statement of Financial Accounting Standard No. 131 which can now be found in Accounting Standards Codification Topic 280.

${ }^{5}$ A core segment characterizes those that comprise the main operations of the company - particular product lines, industries, customer types, etc. Non-core segments include corporate types that predominantly hold non-operating income. See our Research Design section for further discussion.
} 
auditors are unaware of segment level manipulations or do not believe segment-level manipulations are a risk factor, then no significant association between audit fees and segment-level manipulations may exist. Ex-ante the appropriate relationship is unclear.

We test the association between segment-level manipulations and audit fees with a standard audit fee model. Our measure of segment manipulation is the sum of unexpected segment performance across all line-ofbusiness core operating segments for the company, where an individual segment's unexpected performance is equal to a segment's return-on-sales less its respective industry's return on sales. After controlling for abnormal performance, positive (negative) unexpected segment performance for a company would be suggestive of management's use of segment transfers to inflate (deflate) the profitability of particular core segments via non-core segments (Lail et al. 2013). We find that segment manipulations are positively associated with increased audit fees. These results are consistent with a higher risk assessment and/or increased work.

To better understand why auditors would price segment-level manipulation, we consider two additional tests. First, we investigate the association between audit lag (i.e. days to complete the audit) and segment-level manipulations. Using an audit lag model, we find a positive association between segment-level manipulations and audit lag consistent with auditors doing a greater amount of work when clients engage in segment manipulations. Second, we consider whether there is an association between restatements and segment level-manipulations. We find some evidence that segment manipulation is positively associated with the occurrence of a future restatement, suggesting that auditors are justified in assessing a higher risk to these clients. Collectively, these results suggest that auditors are aware of the risk associated with companies that engage in segment level manipulations and that auditors respond appropriately by charging higher fees and doing additional work.

Our results have implications for auditors. First, while we find evidence that auditors are attentive to the risk associated with permissible aggressive reporting, it is unclear whether their response is sufficient to address the risk. Second, auditors may need to discuss evidence suggesting aggressive segment reporting decisions with the audit committee as such behavior may indicate a larger aggressive reporting culture. Third, our findings suggest that when auditors detect segment manipulation, they also perform additional work. Audit committees should consider providing additional resources when auditors can provide evidence that this resource request is linked to observable risk factors.

In the next section, we provide background literature that motivates the study leading to our research question. In Section III, we describe the research design and sample selection process. Section IV provides our results; Section V concludes.

\section{PRIOR LITERATURE}

\section{Classification Shifting and Segment Reporting}

Given earnings management is pervasive and costly to investors (Levitt 1998; Healy and Wahlen 1999; Graham et al. 2005), auditors are expected to detect and prevent it. Recent studies have found that if auditors are effective at deterring accruals-based earning management, then managers use alternative strategies to manipulate earnings. As predicted in Ewert and Wagenhofer (2005)'s analytical model, Chi et al. (2011) find that when auditors constrain accruals, managers engage in more extensive real earnings management. Cohen et al. (2008) show that in the post-SOX era, management is more likely to employ real earnings management strategies because of the perceived increase in the auditor's effectiveness at constraining accruals. Yet, real earnings management is arguably more detrimental to share value than accrual management because managers destroy real long-term value to achieve short-term earnings goals (Roychowdhury 2006).

As an alternative, managers may use a form of classification management to achieve reporting goals (McVay 2006; Fan et al. 2010; Fan and Liu 2012). Classification management involves distorting how specific items are classified on the financial statements by shifting these costs from core operations in order to make them appear more transitory in nature. Classification management is not isolated to vertical shifting at the consolidated level (i.e., from operating expenses to non-operating losses); horizontal classification characterizes the approach of 
shifting revenue and expenses between segments (i.e., from core to "other" segments). The horizontal manipulation of segment performance became a more likely strategy with the introduction of SFAS 131. The pronouncement, effective at the end of 1998, addressed many of the informational demands with its "through the eyes of management" approach to segment reporting whereby companies are required to disaggregate segment performance into core operating segments - those segments of the company evaluated by key internal decision makers. ${ }^{6}$ This approach to segment definitions, as well as not prescribing a particular measure for segment earnings, has introduced a large amount of subjectivity. SFAS 131 also does not require an allocation of corporate overhead costs to the core segments. As a result, considerable discretion exists in how management distributes these expenses, if at all (see SFAS 131, paragraphs 81 and 84).

This setting provides a unique opportunity to examine the level of aggressiveness in management's reporting behavior as well as determine if auditors respond to manipulated segment-level representations put forth by upper management. Managers may distort segment information by aggregating segments with very different performance characteristics to enhance the reported performance of core segments (Harris 1998; Botosan and Stanford 2005; Ettredge et al. 2006; Berger and Hann 2003, 2007; Bens et al. 2011). Additionally, managers may transfer expenses between segments in order to improve the reported performance of core segments (Lail et al. 2013). Alfonso et al. (2012) investigate the segment-to-firm reconciliation and find that firms with higher leverage, losses, and high earnings volatility are more likely to report reconciliations that do not sum to reported consolidated performance.

Managers may prefer segment manipulation over other earnings management strategies such as accruals management. Unlike accruals management, segment manipulations do not reverse in the subsequent years. Similar to real earnings management, segment manipulations remain in conformity with GAAP. ${ }^{7}$ Yet, unlike real earnings management, segment manipulations do not negatively impact the long-term performance of the company. A downside to segment classification shifting is the potential creation of internal conflicts between segment managers; however, upper management's ultimate concern is with the performance of the company and the company's stock. Management may believe that classification shifting facilitates meeting these goals. In addition, upper management would be cognizant of true segment performance which should alleviate potential internal conflicts between segment managers.

\section{Auditors and Segment Reporting}

While possibly conforming to the technical requirements of the reporting standards, segment manipulations may be indicative of an aggressive reporting strategy. If auditors detect aggressive reporting strategies, they should be wary of the tone at the top culture established by management for the entire company. Tone at the top can be a significant audit issue in that it signals to employees the importance of meeting short-term reporting goals. Prior work has found that auditors charge higher fees to clients that engage in aggressive reporting behavior such as accruals management (Choi et al. 2010, Abbott et al. 2006, Gul et al. 2003, Schelleman and Knechel 2010). There is also evidence that auditors price real earnings management even though it is in compliance with GAAP (Sohn 2011). This suggests that even if segment-level manipulations technically comply with GAAP standards, the auditor may still elect to price them.

What makes our research setting particularly interesting is that ex-ante it is not obvious if auditors consider segment reporting an area that deserves special attention. The auditing standards regarding segments in existence prior to the enactment of the PCAOB 2010 risk assessment suite noted that "the auditor is not required to apply procedures as extensive as would be necessary to express an opinion on the segment information taken by itself." Essentially, the auditor must verify that the same segment reporting measures are used for internal and external reporting, a requirement of SFAS 131. This appears to be a relatively straightforward audit task consisting of the review of internal segment reports and management's segment footnotes. Additionally, the PCAOB risk assessment

\footnotetext{
${ }^{6}$ Specific auditor guidelines relating to segment reporting can be found under PCAOB AU Section 9326.28 - .41: "Applying Auditing Procedures to Segment Disclosures in Financial Statements" for fiscal years ending on December 15, 2010 or sooner.

${ }^{7}$ For a detailed background on real earnings management, see Roychowdhury (2006).
} 
suite expects auditors to focus their efforts on higher risk areas. Bowlin (2011) finds that if the auditors do not perceive an item as a strategic risk they allocate fewer resources to auditing that item.

Recently regulators have shown an increased interest in segment disclosures. The SEC has expressed concerns that the disaggregation process and footnote disclosures are inconsistent with segment reporting standards (Johnson 2010). Over one-quarter of all SEC comment letters regarding accounting rule violations specifically discuss segment disclosure problems. ${ }^{8}$ Further, in 2005, the PCAOB inspection report for Ernst \& Young specifically identified that the firm's audit procedures missed "improper aggregation of reporting segments [which] resulted in the offsetting of operating profits at one segment with losses at another" (PCAOB 2005). Paul and Largay (2005) conclude that all stakeholders in the financial reporting process should be aware of the complicity of auditors in segment-level misreporting.

\section{Research Question}

If segment reporting is not considered a significant audit issue, it is unclear if auditors will be sensitive to risks associated with segment classification manipulation. To assess auditor sensitivity, we consider whether there is an association between segment-level manipulations and audit fees. In general, auditors respond to risk factors by charging the client a risk premium and/or doing additional testing, both of which result in higher fees (Hay et al. 2006). Competing arguments can be made for audit fees to be positively, negatively or not associated with segmentlevel manipulations.

Even if auditors detect evidence of segment-level manipulations, it also remains unclear whether this will result in increased audit fees. In the Sarbanes-Oxley era, the audit committee plays a critical role in authorizing additional audit testing and settling auditor-management disputes. When dealing with auditor-management disputes, the audit committee's decisions are highly dependent upon the clarity of the underlying standard (Klein 2002; Gendron et al. 2004). Agoglia et al. (2011) finds that auditors have little support from the audit committee when dealing with imprecise standards. Given the subjective nature of segment reporting, it would be unlikely that an auditor could persuade an audit committee to authorize further work or require that the segment disclosures be amended.

While the previous argument suggests that the risk associated with segment-level manipulations may go undetected by auditors, auditors have incentives to detect and price segment-level manipulations. The SEC comment letters and PCAOB inspection reports suggest that regulators expect auditors to be aware of segment issues. Therefore, auditors should assess a higher level of engagement risk for their multi-segment clients that show evidence of classification management. A higher engagement risk results in higher audit fees, more extensive use of high-risk specialist personnel and industry experts, more intensive testing, and more thorough reviews (Bedard and Johnstone 2004). The auditor may also assign a higher engagement risk because of the heightened litigation risk associated with earnings management in general (St. Pierre and Anderson 1984; Heninger 2001).

The presence of segment-level manipulations could also be evidence of a compromised audit. In other words, management may be able to persuade the auditor to tolerate segment-level manipulations if fees are high. Choi et al. (2010) find that when auditors are paid abnormally high fees, they are more likely to permit aggressive accruals management. Likewise, the auditors' willingness to tolerate segment-level manipulation may increase with client fees.

\footnotetext{
${ }^{8}$ As reported in the Audit Analytics Database as of June 30, 2012. Note: the Audit Analytics database classifies all comment letters into six categories (Accounting Standards, Mergers \& Acquisitions, New and Secondary Registrations, Non Standard and Other Disclosures, Operational Control \& Risk Assessments, and Securities Regulations) and over 2,500 subcategories. Consider the following example from Macy's (received May 23, 2012): "We note you aggregate your operating divisions into one reportable segment. Please clarify for us and in your disclosure whether your operating divisions are operating segments. Given the significant growth of your dot com/online and ecommerce businesses in recent years, please explain to us how you considered them, along with catalog sales, if applicable, as reportable segments. If so, explain to us how macy's.com and bloomingdales.com continue to meet the aggregation criteria within ASC 280-10-50- 11 for aggregation. In doing so, please provide us the data and the substantive factors you considered in determining that the segment(s) have similar economic characteristics including exhibiting similar long-term prospects."
} 
A negative association between audit fees and segment manipulations is a possibility if the presence of segment-level manipulations is indicative of the auditor failing to exert sufficient effort to detect manipulations. If management is able to effectively manipulate segment-level reporting, the auditor may not have performed sufficient testing of the segment disclosures as compared to what may be expected from regulatory agencies. Given the correlation between audit work and audit quality, low audit quality may be accompanied by low audit fees. Blankley et al. (2012) find that abnormally low audit fees are associated with future restatements, and Frankel et al. (2002) suggest that auditors are more likely to allow biased financial reporting by low-fee clients than by high-fee clients.

Because strong theoretical arguments exist for audit fees to be positively, negatively, or not associated with segment-level manipulations, we formally state our research question in the null as:

Hypothesis: There is no relation between audit fees and segment-level manipulations.

\section{RESEARCH DESIGN \& SAMPLE SELECTION}

\section{Audit Fee Model}

To determine the influence of segment-level manipulation on audit fees, we use a two-stage approach analyzing data from 2005 through 2009. In the first stage, we estimate segment-level manipulation through a methodology that focuses on reported core segment performance versus expected core segment performance. We define core segment earnings as the sum of operating segment earnings, which specifically excludes any "corporate" or "other" segment types that contain non-operating income and/or expenses. While not all multi-segment companies utilize an "other" segment, many disclose such a segment that captures items including corporate-level or headquarter costs, smaller segments not required for disclosure, and other costs typically not allocated to the core segments or not easily attributed to a particular segment. Common other expenses include pension, research and development, options, and net interest costs. We require the presence of this "other" segment as it facilitates reallocations. We specifically exclude this other segment from our calculation for core segment earnings as this segment may be a conduit for shifting (Lail et al. 2013).

We calculate expected core segment earnings using an industry-adjusted return on sales model similar to Berger and Hann $(2003,2007)$ and calculate unexpected core segment earnings as the difference between actual and expected core segment earnings. Unexpected core segment earnings arise when actual core earnings for a particular firm-year are higher (or lower) than is typical when compared to that segments' industries. Positive unexpected core segment earnings occur for two reasons: (1) the segment is truly outperforming the other segments in its industry; or (2) management has used inter-segment transfers to boost the performance of the segment either at the detriment of another segment or by transferring costs to the other segment. Our research question focuses on the latter; therefore, we control for overall firm performance in an attempt to isolate manipulations in segment reporting. ${ }^{9}$

Specifically, unexpected core segment earnings $\left(S E G_{-} M A N\right)$ are defined as the weighted-average unexpected return on sales across all $s$ segments for firm $i$ in year $t$, excluding non-operating segments. For each segment $s$, we measure segment return on sales $(R O S)$ as the segment's operating performance divided by segment sales. We compare this to the return on sales for the same industry as segment $s$ (IROS). Industries are defined based on the lowest level of SIC code, and a minimum of ten observations must be available within the industry to compute IROS. ${ }^{10}$ We then weight the difference in ROS and IROS for each segment by its proportion of segment

\footnotetext{
${ }^{9}$ Our argument follows from the typical agency motive where underperformance of segments is undesirable to disclose due to market consequences. The segment literature has documented such manipulative behavior by managers (see Berger and Hann 2003). An alternative motive suggesting negative unexpected core segment earnings is proprietary concerns. Harris (1998) documents that managers are motivated to hide strongly performing segments in less competitive industries to maintain an advantage; however, researchers have been unable to consistently document proprietary cost motives.

${ }^{10}$ We use a four-digit SIC industry match when possible, but where the number of segment-years is insufficient to calculate an appropriate industry return-on-sales $(<10)$, we next match the segment with a three-digit SIC return-on-sales. This is necessary
} 
sales $\left(\operatorname{Sales}_{i, t}^{S}\right)$ to the sum of all segment sales $\left(\right.$ Sales $\left._{i, t}\right)$ in year $t .{ }^{11}$

$$
S E G_{-} \text {MAN }_{i, t}=\sum_{s=1}^{S}\left[\left(\operatorname{ROS}_{i, t}^{S}-\operatorname{IROS}_{t}^{S}\right) * \frac{\text { Sales }_{i, t}^{S}}{\text { Sales }_{i, t}}\right]
$$

In the second stage, we use a standard audit fee model to determine the association between audit fees and our measure of segment manipulation $\left(S E G \_M A N\right)$. Specifically, we regress logged audit fees $(L A F)$ on variables controlling for audit effort, risk, and industry using the robust cluster technique suggested by Petersen (2009). Our fee model is adapted from recent prior studies (e.g., DeFond et al. 2002; Whisenant et al. 2003; Francis and Wang 2005; Krishnan et al. 2005; Ghosh and Pawlewicz 2009; Choi et al. 2010):

Audit Fee Model:

$$
\begin{aligned}
& L A F_{i, t}=\beta_{0}+\beta_{1} S E G_{-} M A N_{i, t}+\beta_{2} L T A_{i, t}+\beta_{3} C R_{i, t}+\beta_{4} C A_{-} T A_{i, t}+\beta_{5} A R I N V_{i, t}+\beta_{6} R O A_{i, t} \\
& +\beta_{7} \text { LOSS }_{i, t}+\beta_{8} \text { FOREIGN }_{i, t}+\beta_{9} \text { MERGER }_{i, t}+\beta_{10} \text { BUSY }_{i, t}+\beta_{11} \text { LEV }_{i, t}+\beta_{12} \text { INTANG }_{i, t}
\end{aligned}
$$

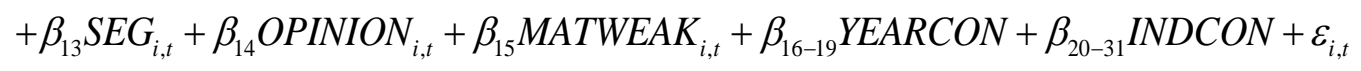

where,
$L A F \quad=$ logarithm of audit fees;
$S E G \_M A N=$ segment manipulation variable discussed above;
LTA = logarithm of end of year total assets;
$C R \quad=$ current assets divided by current liabilities;
CA_TA = current assets divided by total assets;
ARINV = sum of accounts receivable and inventory divided by total assets
ROA = earnings before interest and taxes divided by total assets;
LOSS $\quad=1$ if firm incurred a loss and 0 otherwise;
FOREIGN $\quad=1$ if firm has any foreign operations, 0 otherwise;
MERGER $\quad=1$ if the firm reported the impact of a merger or acquisition on net income, 0 otherwise;
$B U S Y$
LEV
INTANG
SEG
OPINION
MATWEAK
$=1$ if a company's fiscal year is in December or January, 0 otherwise;
= long-term debt divided by total assets;
$=$ ratio of intangible assets to total assets;
$=$ logarithm of number of business segments;
$=1$ if the auditor issues a going concern audit opinion, 0 otherwise;
$=1$ if the client receives a material weakness opinion in the current or previous year, 0
otherwise;
YEARCON = Year Fixed Effects;
INDCON $\quad=$ Industry Fixed Effects.

The coefficient on $S E G_{-} M A N\left(\beta_{1}\right)$ specifically addresses our research question. A positive (negative) coefficient would be indicative of higher (lower) audit fees when segment manipulation is greater. Knowing that our $S E G \_M A N$ measure could be indicative of abnormal performance, we include ROA and LOSS in an attempt to

for less than $10 \%$ of our segments. Finally, we use a two-digit SIC match when a three-digit match in unavailable. This is necessary for less than $1 \%$ of our segments.

${ }^{11}$ Prior research also measures unexpected core earnings using a classification model at the consolidated level (McVay 2006). For example, expected core earnings at the consolidated level can be modeled as a function of lagged core earnings, lagged accruals, sales, asset turnover, and stock returns (Fan et al. 2010). Employing such a model at the segment level poses a considerable challenge due to lack of segment-specific data. Therefore, we calculate unexpected core segment earnings using an industry-adjusted return-on-sales approach similar to Berger and Hann (2003, 2007). 
isolate the manipulation we intend to capture. While we expect audit fees to be positively associated with abnormal performance, after controlling for firm-level performance, we expect $\beta_{1}$ to illustrate the association between audit fees and segment manipulation.

We control for audit effort with LTA, FOREIGN, MERGER, SEG and OPINION, and audit risk with $C R$, CA_TA, ARINV, ROA, LOSS, and INTANG. LEV captures the long-term financial structure of the client. BUSY is an indicator variable if the company has a busy season year-end. MATWEAK is included to control for the presence of a SOX Section 302 material weaknesses in the current or prior fiscal year. ${ }^{12}$ Finally, we also include year fixed-effects and consistent with Ashbaugh et al. (2003), we include industry controls (INDCON).

\section{$\underline{\text { Sample }}$}

Our sample is a combination of three data sets - audit fees from Audit Analytics, company information from Compustat, and segment data from the segment portion of the Compustat database - from 2005 to 2009. Our sample period begins in 2005 to ensure that all firms were required to comply with SOX 404 internal control reporting. ${ }^{13}$ Consistent with prior literature, we exclude firms in the financial services industry (SIC 6000-6999), foreign filers, and those lacking any data required for variable calculations. ${ }^{14}$ Our measure of segment manipulation requires that we limit the sample to firms with multiple line-of-business segments which equates to 9,735 firm years in our sample period. Approximately $40 \%$ have an identifiable "other" segment necessary for our study, and we require at least ten companies per year within each industry to calculate $S E G \_M A N$, resulting in a sample of 2,803 firm years. This set of firm-years is then combined with the data from Audit Analytics. We limit our sample to Big $\mathrm{N}$ clients in order to ensure relative homogeneity in audit capacity and also eliminate firms that paid no audit fees or those that paid audit fees to multiple audit firms. Companies paying no fees are unlikely to have normal audits and those employing multiple firms make interpretation of the results problematic. Our final combined sample includes 2,415 firm-years (representing 10,740 segments) having all the necessary data for our models.

\section{RESULTS}

As a preliminary analysis, we examine basic descriptive statistics (reported in Table 1). As expected, our variable of interest, $S E G_{-} M A N$, is close to zero as it essentially represents a residual of performance. Only for those companies with segments that are strongly out-performing their respective competition or manipulating performance would we expect SEG_MAN to be positive and significant. Our average audit fees are over two million dollars, consistent with our sample covering the relatively large firms that have multiple segments. Sample companies average 4.4 segments (unlogged from the $S E G$ variable) with a strong foreign presence (FOREIGN), have kept its auditor for at least nine years (TENURE), are profitable (EPR), and have positive free cash flow (FREEC). We find $17 \%$ of our sample received a material weakness opinion suggesting many firms in our sample had weak internal controls. From our correlation analysis in Table 2, the primary relationships of interest are those with SEG_MAN. We find that segment manipulation is positively associated with audit fees as well as the likelihood of future restatements (RES_FUT).

Table 3 shows the results for our audit fee model. Consistent with prior research, our model explains approximately $80 \%$ of the variation in audit fees. With the exception of ARINV, BUSY, and OPINION, all variables are at least significant at the $10 \%$ level. We find a positive significant association between $S E G \_M A N$ and audit fees

\footnotetext{
${ }^{12}$ In an untabulated robustness test, we also consider an internal control measure based on SOX Section 404 reports. We elect to report the 302 measure as increasingly few firms report SOX Section 404 material weaknesses. According to the Audit Analytics Database, the number of SOX Section 404 material weaknesses reported each year has declined from 2004 to 2010 which corresponds with a decrease in the percent of firms receiving a material weakness on the 404 internal control opinion from 12.5 percent in 2004 to 3.4 percent in 2010.

${ }^{13}$ Audit fees have only been a required disclosure since 2000. Prior to 2005, there was no auditor provided opinion on internal controls.

${ }^{14}$ We exclude foreign filers because they were not required to issue an internal control opinion prior to July 2007; in addition, the audit lag function may depend upon the country of operations.
} 
(coefficient 0.82, t-stat 2.62). This suggests that after controlling for other risk factors, auditors price segment-level manipulations. As previously explained, ex-ante plausible arguments existed for a positive, negative or no relation between audit fees and segment manipulations. With respect to our research question, we find that auditors both identify and price segment manipulations. Because our proxy for segment manipulation, SEG_MAN, could also represent abnormal competitive advantages for a firm on a segment-by-segment basis, we consider whether firms that perform well are charged higher fees. Specifically, we note that $R O A$, a proxy for performance, is negatively associated with audit fees (t-stat 4.25). Thus, we conclude that the positive association found in Table 3 is indicative of segment manipulation, not segment performance, providing upward pressure on audit fees.

Table 1

\begin{tabular}{|c|c|c|c|c|c|}
\hline \multicolumn{6}{|c|}{ Descriptive Statistics } \\
\hline Continuous Variables & Mean & Median & Std. Dev. & $25 \%$ & $75 \%$ \\
\hline$L A F$ & 14.55 & 14.48 & 1.04 & 13.88 & 15.23 \\
\hline$S E G \_M A N$ & $(0.08)$ & 0.00 & 2.13 & $(0.03)$ & 0.05 \\
\hline$L T A$ & 7.35 & 7.34 & 1.67 & 6.33 & 8.44 \\
\hline$C R$ & 2.08 & 1.65 & 1.69 & 1.18 & 2.35 \\
\hline CA_TA & 0.40 & 0.38 & 0.22 & 0.22 & 0.55 \\
\hline ARINV & 0.25 & 0.23 & 0.16 & 0.12 & 0.35 \\
\hline$R O A$ & 0.08 & 0.08 & 0.17 & 0.05 & 0.12 \\
\hline$L E V$ & 0.24 & 0.22 & 0.22 & 0.09 & 0.35 \\
\hline INTANG & 0.22 & 0.17 & 0.21 & 0.05 & 0.35 \\
\hline SEG & 1.49 & 1.39 & 0.63 & 1.39 & 2.08 \\
\hline BTM & $(1.29)$ & 0.45 & 41.74 & 0.26 & 0.66 \\
\hline$L A G$ & 4.14 & 4.09 & 0.24 & 4.03 & 4.28 \\
\hline TENURE & 2.32 & 2.20 & 1.01 & 1.61 & 3.00 \\
\hline$E P R$ & 1.44 & 2.07 & 46.29 & 0.99 & 4.25 \\
\hline FIN & 0.12 & 0.03 & 0.32 & 0.00 & 0.13 \\
\hline FREEC & 0.03 & 0.04 & 0.16 & $(0.00)$ & 0.08 \\
\hline \multicolumn{6}{|l|}{ Rates of Occurrence } \\
\hline LOSS & 0.09 & & & & \\
\hline FOREIGN & 0.66 & & & & \\
\hline MERGER & 0.18 & & & & \\
\hline$B U S Y$ & 0.75 & & & & \\
\hline OPINION & 0.01 & & & & \\
\hline MATWEAK & 0.17 & & & & \\
\hline$R E S \_F U T$ & 0.08 & & & & \\
\hline EPSGROW & 0.08 & & & & \\
\hline EXITEM & 0.04 & & & & \\
\hline$A C C$ & 0.32 & & & & \\
\hline$L A C C$ & 0.54 & & & & \\
\hline
\end{tabular}

Variable Definitions are as follows: $L A F=\operatorname{logarithm}$ of audit fees; $S E G_{-} M A N=$ segment manipulation variable; $L T A=$ logarithm of end of year total assets (in 1000s); $C R=$ current ratio; $C A \_T A=$ current assets divided by total assets; $A R I N V=$ sum of accounts receivable and inventory divided by total assets; $R O A=$ earnings before interest and taxes divided by total assets; $L E V=$ long term debt divided by total assets; INTANG = ratio of intangible assets to total assets; SEG = logarithm of number of business segments; $B T M=$ book-to-market ratio; $L A G=$ logarithm of audit lag; TENURE = logarithm of the number of years the auditor has been the auditor for the client; $E P R=$ income from continuing operations scaled by market capitalization at the end of the year; FIN = the sum of cash raised from the issuance of long-term debt, common stock and preferred stock deflated by total assets; $F R E E C=$ the sum of cash from operations less average capital expenditures scaled by lagged total assets; LOSS = 1 if firm incurred a loss, 0 otherwise; FOREIGN $=1$ if firm has any 0 foreign sales, 0 otherwise; MERGER = 1 if the firm reported the impact of a merger or acquisition on net income, 0 otherwise; $B U S Y=1$ if a company's fiscal year is in January or December, 0 otherwise; $O P I N I O N=1$ if the auditor issued a going concern audit opinion, 0 otherwise; $M A T W E A K=1$ if the client receives a 302 material weakness opinion in the current or previous year, 0 otherwise; RES_FUT = 1 if the firm restates this year's income, 0 otherwise; EPSGROW $=1$ if the company had positive earnings change for four consecutive quarters, 0 otherwise; $E X I T E M=1$ if the client reports an extraordinary item, 0 otherwise; $A C C=1$ if the firm was an accelerated filer, 0 otherwise; $L A C C=1$ if the firm was a large accelerated filer. 


\begin{tabular}{|c|c|c|c|c|c|c|c|c|c|c|c|c|c|c|c|}
\hline & & & & & & & able 2 & relations & & & & & & & \\
\hline & & $(1)$ & (2) & (3) & (4) & (5) & (6) & (7) & $(8)$ & (9) & $(10)$ & $(11)$ & (12) & (13) & (14) \\
\hline (1) & $L A F$ & & & & & & & & & & & & & & \\
\hline (2) & $L A G$ & $(0.23)^{*}$ & & & & & & & & & & & & & \\
\hline (3) & RES_FUT & $(0.02)$ & $0.07 *$ & & & & & & & & & & & & \\
\hline (4) & SEG_MAN & $0.07 *$ & $(0.01)$ & 0.01 & & & & & & & & & & & \\
\hline (5) & $L T A$ & $0.80 *$ & $(0.39)^{*}$ & $(0.04)^{*}$ & $0.08 *$ & & & & & & & & & & \\
\hline (6) & $C R$ & $(0.30)^{*}$ & $0.06^{*}$ & $(0.01)$ & $(0.04)^{*}$ & $(0.36)^{*}$ & & & & & & & & & \\
\hline (7) & CA_TA & $(0.15)^{*}$ & $0.10 *$ & 0.01 & $(0.05)^{*}$ & $(0.45)^{*}$ & $0.47 *$ & & & & & & & & \\
\hline (8) & ARINV & $(0.01)$ & $0.05^{*}$ & $(0.01)$ & $0.05^{*}$ & $(0.25)^{*}$ & $0.06 *$ & $0.70 *$ & & & & & & & \\
\hline (9) & $R O A$ & $(0.13)^{*}$ & $(0.14 *$ & $(0.04)^{*}$ & $0.31 *$ & $0.22 *$ & $(0.03)$ & $(0.06) *$ & $0.12 *$ & & & & & & \\
\hline (10) & LOSS & $(0.20)^{*}$ & $0.21^{*}$ & $0.09^{*}$ & $(0.15)^{*}$ & $(0.30)^{*}$ & $0.21 *$ & $0.19^{*}$ & $(0.05)^{*}$ & $(0.44)^{*}$ & & & & & \\
\hline (11) & FOREIGN & $0.33 *$ & $(0.03)$ & 0.01 & $0.06^{*}$ & $0.09 *$ & $0.10 *$ & $0.30 *$ & $0.33^{*}$ & $0.10 *$ & $(0.07)^{*}$ & & & & \\
\hline (12) & $M E R G E R$ & $0.13 *$ & $(0.01)$ & 0.01 & 0.02 & $0.08 *$ & $(0.03)$ & $(0.07)^{*}$ & 0.00 & 0.01 & $(0.04)$ & $0.09 *$ & & & \\
\hline (13) & $B U S Y$ & $0.07 *$ & $(0.03)$ & $(0.12)^{*}$ & $(0.02)$ & $0.13 *$ & $(0.08)^{*}$ & $(0.16)^{*}$ & $(0.14)^{*}$ & $(0.03)$ & 0.00 & $(0.07)^{*}$ & $(0.00)$ & & \\
\hline (14) & $L E V$ & $0.11 *$ & $0.04 *$ & $(0.02)$ & 0.00 & $0.17 *$ & $(0.22)^{*}$ & $(0.42)^{*}$ & $(0.27)^{*}$ & $0.08 *$ & $(0.08)^{*}$ & $(0.16)^{*}$ & $0.08 *$ & $0.11 *$ & \\
\hline (15) & INTANG & $0.25^{*}$ & $(0.02)$ & $(0.02)$ & $0.04 *$ & $0.17 *$ & $(0.14)^{*}$ & $(0.30)^{*}$ & $(0.17)^{*}$ & $0.08 *$ & $(0.15)^{*}$ & $0.25^{*}$ & $0.26^{*}$ & $(0.01)$ & $0.17 *$ \\
\hline (16) & $S E G \_M A N$ & $0.07 *$ & $(0.07)^{*}$ & $(0.01)$ & 0.03 & $0.05^{*}$ & 0.03 & $(0.00)$ & 0.03 & $0.05 *$ & $(0.07)^{*}$ & $(0.02)$ & 0.01 & 0.00 & $(0.05)^{*}$ \\
\hline (17) & OPINION & $(0.04)$ & $0.16^{*}$ & $(0.01)$ & $(0.05)^{*}$ & $(0.11)^{*}$ & $(0.07)^{*}$ & 0.03 & $(0.01)$ & $(0.35)^{*}$ & $0.20 *$ & $(0.02)$ & $(0.04)$ & 0.02 & $(0.04)$ \\
\hline (18) & MATWEAK & 0.03 & $0.32 *$ & $(0.10)^{*}$ & 0.01 & $(0.15)^{*}$ & $(0.00)$ & $0.09 *$ & $0.08 *$ & $(0.07)^{*}$ & $0.14 *$ & $0.04 *$ & 0.01 & $(0.03)$ & $(0.02)$ \\
\hline (19) & EPSGROW & $(0.05) *$ & $0.07 *$ & $(0.04)^{*}$ & 0.01 & 0.03 & $(0.06) *$ & $(0.07)^{*}$ & $(0.06)^{*}$ & 0.00 & $(0.08)^{*}$ & $(0.06) *$ & $(0.05) *$ & $0.06^{*}$ & $0.13 *$ \\
\hline (20) & BTM & $(0.06)^{*}$ & $(0.05) *$ & 0.02 & $(0.00)$ & $(0.03)$ & 0.03 & 0.01 & 0.01 & 0.01 & (0.03) & -0.01 & 0.02 & $(0.02)$ & 0.04 \\
\hline (21) & EXITEM & $0.12 *$ & 0.03 & $0.05 *$ & 0.01 & $0.12 *$ & $(0.06)^{*}$ & $(0.06)^{*}$ & $(0.04)$ & $(0.00)$ & $(0.02)$ & 0.02 & 0.02 & $0.05^{*}$ & 0.01 \\
\hline (22) & TENURE & $0.16^{*}$ & $(0.20)^{*}$ & $(0.01)$ & 0.02 & $0.15^{*}$ & $(0.02)$ & $0.06^{*}$ & $0.09 *$ & $0.05^{*}$ & $(0.07)^{*}$ & $0.10^{*}$ & $(0.03)$ & $(0.04)^{*}$ & $(0.15)^{*}$ \\
\hline (23) & $A C C$ & $(0.32)$ & $0.21 *$ & $0.06^{*}$ & $(0.05)^{*}$ & $(0.44)^{*}$ & $0.14^{*}$ & $0.15^{*}$ & $0.09 *$ & $(0.12)^{*}$ & $0.16^{*}$ & $(0.06)^{*}$ & $(0.01)$ & $(0.11)^{*}$ & $(0.05)^{*}$ \\
\hline (24) & $L A C C$ & $0.48 *$ & $(0.44)^{*}$ & $(0.04)^{*}$ & $0.05^{*}$ & $0.58 *$ & $(0.13)^{*}$ & $(0.17)^{*}$ & $(0.09)^{*}$ & $0.18^{*}$ & $(0.24)^{*}$ & $0.14^{*}$ & $0.06^{*}$ & $0.09^{*}$ & $(0.01)$ \\
\hline (25) & $E P R$ & $0.05^{*}$ & $(0.05)^{*}$ & 0.01 & 0.03 & $0.06^{*}$ & $(0.11)^{*}$ & 0.00 & $0.05^{*}$ & $0.13^{*}$ & $(0.13)^{*}$ & 0.01 & 0.02 & $(0.02)$ & 0.01 \\
\hline (26) & FIN & 0.02 & $0.06^{*}$ & 0.03 & 0.01 & -0.02 & $(0.08)^{*}$ & $(0.03)$ & $0.08^{*}$ & 0.03 & 0.01 & $(0.01)$ & $0.10^{*}$ & $(0.03)$ & $0.28 *$ \\
\hline (27) & FREEC & $\begin{array}{l}0.14^{*} \\
(15)\end{array}$ & $\begin{array}{l}(0.12)^{*} \\
(16)\end{array}$ & $\begin{array}{l}(0.01) \\
(17)\end{array}$ & $\begin{array}{l}0.26^{*} \\
(18)\end{array}$ & $\begin{array}{l}0.17 * \\
(19)\end{array}$ & $\begin{array}{l}0.02 \\
(20)\end{array}$ & $\begin{array}{l}0.01 \\
(21)\end{array}$ & $\begin{array}{l}0.09^{*} \\
(22)\end{array}$ & $\begin{array}{l}0.88^{*} \\
(23)\end{array}$ & $\begin{array}{l}(0.33)^{*} \\
(24)\end{array}$ & $\begin{array}{l}0.15^{*} \\
(25)\end{array}$ & $\begin{array}{l}0.04 * \\
(26)\end{array}$ & $\begin{array}{l}(0.03) \\
(27)\end{array}$ & -0.01 \\
\hline (15) & INTANG & & & & & & & & & & & & & & \\
\hline (16) & $S E G \_M A N$ & $0.04 *$ & & & & & & & & & & & & & \\
\hline (17) & OPINION & $(0.06) *$ & $(0.04)$ & & & & & & & & & & & & \\
\hline (18) & MATWEAK & $(0.06)^{*}$ & $(0.04)$ & $0.11 *$ & & & & & & & & & & & \\
\hline (19) & EPSGROW & $(0.01)$ & $(0.02)$ & $(0.04)$ & $(0.03)$ & & & & & & & & & & \\
\hline (20) & $B T M$ & 0.01 & 0.00 & $(0.35)^{*}$ & $(0.08)^{*}$ & 0.01 & & & & & & & & & \\
\hline (21) & EXITEM & $(0.01)$ & 0.01 & $0.05^{*}$ & $0.08^{*}$ & 0.02 & $(0.10)^{*}$ & & & & & & & & \\
\hline (22) & TENURE & $(0.04)$ & $0.19 *$ & $(0.04)^{*}$ & $(0.11)^{*}$ & $(0.06)^{*}$ & $0.04 *$ & 0.03 & & & & & & & \\
\hline (23) & $A C C$ & $(0.06)^{*}$ & $(0.02)$ & $0.06^{*}$ & $0.12 *$ & $(0.05)^{*}$ & 0.02 & $(0.03)$ & $(0.05)^{*}$ & & & & & & \\
\hline (24) & $L A C C$ & $0.12 *$ & $0.09^{*}$ & $(0.12)^{*}$ & $(0.17)^{*}$ & $(0.18)^{*}$ & $0.05^{*}$ & 0.04 & $0.18^{*}$ & $(0.74)^{*}$ & & & & & \\
\hline (25) & AUD_IND & $0.09 *$ & $(0.01)$ & $(0.03)$ & $(0.04)^{*}$ & $0.07 *$ & 0.00 & $(0.01)$ & $(0.01)$ & $(0.10)^{*}$ & 0.02 & & & & \\
\hline (26) & $E P R$ & $0.05^{*}$ & $(0.01)$ & $(0.06)^{*}$ & $(0.01)$ & 0.00 & 0.00 & 0.00 & $0.06^{*}$ & $(0.04)^{*}$ & $0.05^{*}$ & 0.05 & & & \\
\hline (27) & FIN & 0.04 & $(0.04)$ & 0.01 & 0.03 & $(0.01)$ & 0.00 & $(0.01)$ & $(0.07)^{*}$ & $0.05 *$ & $(0.06)^{*}$ & 0.01 & $(0.07)$ & & \\
\hline (28) & FREEC & $0.14 *$ & $0.05^{*}$ & $(0.37)^{*}$ & $(0.05)^{*}$ & $(0.02)$ & 0.01 & $(0.01)$ & $0.07 *$ & $(0.10)^{*}$ & $0.15^{*}$ & $0.14^{*}$ & 0.00 & 0.00 & \\
\hline
\end{tabular}

* significant at the $5 \%$ level. See Table 1 for variable definitions 
Table 3

\begin{tabular}{llll} 
Dependent Variable: $L A F$ & Audit Fee Model & & p-value** \\
\hline \hline CONSTANT & Coef & t-stat & 0.00 \\
SEG_MAN & 9.30 & 34.97 & 0.01 \\
LTA & 0.82 & 2.62 & 0.00 \\
CR & 0.57 & 40.96 & 0.00 \\
CA_TA & $(0.08)$ & $(5.36)$ & 0.00 \\
ARINV & 1.28 & 8.64 & 0.51 \\
ROA & 0.11 & 0.65 & 0.00 \\
LOSS & $(0.30)$ & $(4.25)$ & 0.01 \\
FOREIGN & 0.13 & 2.54 & 0.00 \\
MERGER & 0.24 & 5.22 & 0.09 \\
BUSY & 0.05 & 1.68 & 0.00 \\
LEV & 0.01 & 0.14 & 0.00 \\
INTANG & 0.29 & 3.51 & 0.01 \\
SEG & 0.52 & 5.09 & 0.29 \\
OPINION & 0.06 & 2.50 & 0.00 \\
MATWEAK & 0.13 & 1.05 & \\
\hline R-squared & 0.35 & 8.82 & \\
N & 0.80 & & \\
\hline Note: The above & 2,415 & & \\
\hline
\end{tabular}

Note: The above model (2) was estimated using the robust cluster technique by company as suggested in Petersen (2009). Industry and year controls were included.

**All p-values are two-tailed.

See Table 1 for variable definitions.

\section{Further Analysis}

Two possible, but not mutually exclusive, explanations exist as to why audit fees are positively associated with segment-level manipulation: the auditor may either be charging a risk premium or the auditor may be increasing their effort. Under the risk premium argument, auditors charge the client higher fees without doing additional work. Auditors may assess a higher risk premium on firms that manipulate segment performance, suggesting that the tone at the top set by upper management raises some additional concerns for the auditor. This is tantamount to an insurance company charging higher fees to a higher risk client. Under the additional effort argument, the auditor responds to risk associated with segment-level manipulations by conducting additional tests.

To test which of these causes is driving the elevated fees for firms with segment manipulation, we examine audit report lag. Audit report lags are defined as the number of days between the fiscal year-end and the date of the audit report. Prior research indicates that audit report lags are directly related to the amount of work the auditor needs to do (Ashton et al. 1989; Carslaw and Kaplan 1991; Henderson and Kaplan 2000; Knechel and Payne 2001). Thus, a longer lag would be associated with additional audit work. Under a risk premium argument, we would not expect segment manipulations to be associated with audit lag, while for the additional work argument we would expect a positive association between segment manipulation and audit lag. Consistent with Knechel and Sharma (2009) and Krishnan and Yang (2009), we use the following model:

$$
\begin{aligned}
& L A G_{i, t}=\beta_{0}+\beta_{1} S E G_{-} M_{i, t}+\beta_{2} C R_{i, t}+\beta_{3} \text { ROA }_{i, t}+\beta_{4} L_{O S S}+\beta_{5} E_{i, t} S G R O W_{i, t}+\beta_{6} \text { BTM }_{i, t} \\
& +\beta_{7} \text { EXITEM }_{i, t}+\beta_{8} L E V_{i, t}+\beta_{9} \text { BUSY }_{i, t}+\beta_{10} \text { LTA }_{i, t}+\beta_{11} \text { MERGER }_{i, t}+\beta_{12} \text { FOREIGN }_{i, t} \\
& +\beta_{13} \text { SEG }_{i, t}+\beta_{14} \text { OPINION }_{i, t}+\beta_{15} \text { TENURE }_{i, t}+\beta_{16} \text { MATWEAK }_{i, t-(t-1)}+\beta_{17} \text { ACC }_{i, t} \\
& +\beta_{18} L A C C_{i, t}+\beta_{19-22} \text { YEARCON }+\beta_{23-34} I N D C O N+\varepsilon_{i, t}
\end{aligned}
$$

where all variables except those noted below are defined as in model (2):

$L A G=\quad$ logarithm of number of days between when the auditor issues the audit report and the fiscal year end. 


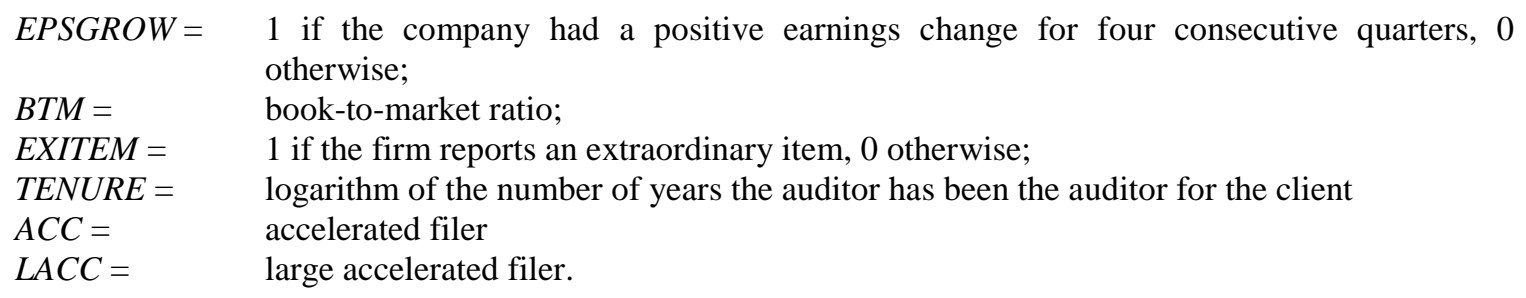

We include six variables to control for audit risk: the current ratio $(C R)$, return on assets $(R O A)$, the incurrence of a loss (LOSS), consistent earnings growth (EPSGROW), book-to-market value $(B T M)$, and the reporting of an extraordinary item (EXITEM). Following Francis (1984), we include leverage (LEV) as a measure of the long-term financial structure of the client. We also include an indicator variable if the company has a fiscal yearend in December or January (BUSY) which proxies for the effect of the audit busy season. We also include five different measures to control for audit effort: total assets (LTA); the presence of mergers (MERGER), foreign operations (FOREIGN), and the number of business segments ( $S E G)$ all of which capture complexity in operations; and the issuance of a going concern audit opinion $(O P I N I O N)$, which captures financial distress. Each of these measures proxies for characteristics of the client that likely require additional audit effort.

In addition, we include several variables to control for firm and company characteristics that could have some influence on audit report lags. We include the length of the auditor's tenure with the client (TENURE) which control for audit efficiency effects (Knechel et al. 2009). We also include variables capturing both the firm's status as an accelerated filer $(A C C)$ and a large accelerated filer $(L A C C)$ to control for the impact of the SEC's filing deadlines on audit lags. To control for internal control quality, we include a variable defined as the presence of a section 302 material weakness in the current or prior fiscal year (MATWEAK). Finally, we include controls for year fixed-effects $(Y E A R C O N)$ and industry fixed-effects $(I N D C O N)$.

Table 4

\begin{tabular}{|c|c|c|c|}
\hline Dependent Variable: $L A G$ & $\begin{array}{c}\text { Audit Lag Mode } \\
\text { Coef }\end{array}$ & t-stat & p-value $* *$ \\
\hline CONSTANT & 4.55 & 106.02 & 0.00 \\
\hline$S E G \_M A N$ & 0.31 & 3.34 & 0.00 \\
\hline$C R$ & $(0.01)$ & $(1.54)$ & 0.12 \\
\hline$R O A$ & 0.01 & 0.16 & 0.88 \\
\hline LOSS & 0.05 & 2.39 & 0.02 \\
\hline EPSGROW & $(0.02)$ & $(0.92)$ & 0.36 \\
\hline BTM & 0.00 & 1.49 & 0.14 \\
\hline EXITEM & 0.03 & 1.09 & 0.28 \\
\hline$L E V$ & 0.06 & 2.21 & 0.03 \\
\hline$B U S Y$ & $(0.00)$ & $(0.13)$ & 0.89 \\
\hline$L T A$ & $(0.03)$ & $(6.36)$ & 0.00 \\
\hline MERGER & 0.02 & 1.42 & 0.16 \\
\hline FOREIGN & 0.03 & 2.65 & 0.01 \\
\hline$S E G$ & 0.00 & 0.21 & 0.84 \\
\hline OPINION & 0.15 & 2.15 & 0.03 \\
\hline TENURE & $(0.01)$ & $(2.99)$ & 0.00 \\
\hline MATWEAK & 0.13 & 8.03 & 0.00 \\
\hline$A C C$ & $(0.13)$ & $(6.59)$ & 0.00 \\
\hline$L A C C$ & $(0.21)$ & (10.99) & 0.00 \\
\hline
\end{tabular}

R-squared

0.35

$\mathrm{N} \quad 2,415$

Note: The above model (3) was estimated using the robust cluster technique by company as suggested in Petersen (2009). Industry and year controls were included.

**All p-values are two-tailed.

See Table 1 for variable definitions. 
As reported in Table 4, our audit lag model explains $35 \%$ of the variation in audit lag. ${ }^{15}$ With respect to segment manipulations (SEG_MAN) we find a significant positive association between lag and segment manipulations $(0.31, \mathrm{t}=3.34)$. This suggests that not only are auditors assessing greater risk to clients (as seen by higher audit fees) when segment disclosures indicate a potential manipulation, the auditors are also exerting greater effort to examine the situation.

As a final consideration, we examine whether a risk premium is justifiable. We examine the association between segment-level manipulations and future restatements. If segment-level manipulations are associated with future restatements, then this suggests a higher engagement risk that would necessitate a risk premium. Consistent with Romanus et al. (2008), Aier et al. (2005), and Richardson et al. (2002), the restatement model we use is:

$$
\begin{aligned}
R E S_{-} F U T_{i, t}= & \beta_{0}+\beta_{1} S E G_{-} \text {MAN }_{i, t}+\beta_{2} \text { EPR }_{i, t}+\beta_{3} \text { EPSGROW }_{i, t}+\beta_{4} \text { LOSS }_{i, t}+\beta_{5} \text { BTM }_{i, t} \\
& +\beta_{6} \text { ROA }_{i, t}+\beta_{7} \text { FIN }_{i, t}+\beta_{8} \text { FREEC }_{i, t}+\beta_{9} L_{i, t}+\beta_{10} L_{i, t}+\beta_{11} \text { FOREIGN }_{i, t} \\
& +\beta_{12} \text { SEG }_{i, t}+\beta_{13} \text { MATWEAK }_{i, t}+\beta_{14-17}{\text { YEARCON }+\varepsilon_{i, t}}
\end{aligned}
$$

where all variables except those noted below are defined as in models (2) and (3):

$\begin{array}{ll}R E S_{-} F U T_{-}= & \begin{array}{l}1 \text { if the firm restates this year's financial statements, } 0 \text { otherwise; } \\ \text { earnings-to-price ratio, defined as income from continuing operations scaled by market } \\ \text { capitalization at the end of the year; }\end{array} \\ \text { financing raised, defined as the sum of additional cash raised from the issuance of long- } \\ \text { term debt, common stock and preferred stock deflated by total assets; } \\ \text { demand for external financing, measured as the sum of cash from operations less average } \\ \text { capital expenditures scaled by lagged total assets; }\end{array}$

Variables capturing market pressure include an earnings multiple $(E P R)$ and book-to-market $(B T M)$ to control for the market's perception of future growth. We include EPSGROW, which proxies for the pressure to maintain a string of earnings increases. We also include an indicator variable to indicate a loss before extraordinary items (LOSS) and return on assets (ROA).

Financial risk is captured with three variables. FREEC proxies for the extent to which the firm needs external financing, and FIN captures the actual amount of financing within the capital markets. We control for leverage $(L E V)$ because evidence suggests that companies with debt covenant constraints upwardly manipulate earnings. To control for complexity, we include variables representing firm size (LTA), foreign operations $(F O R E I G N)$, and the number of business segments $(S E G)$. Finally, we also include the internal control indicator variable, MATWEAK, which we expect to be positively associated with restatements. We also include controls for year fixed-effects $(Y E A R C O N)$.

As reported in Table 5, we find evidence that segment manipulations are positively associated with future restatements $(\mathrm{p}<0.05$ one-tailed). While segment manipulations are not GAAP violations, the existence of such behavior is either indicative of other manipulative behavior or egregious enough on its own to mislead financial statement users. This evidence provides further support for regulators' push for greater focus to be given to segment disclosures.

\footnotetext{
${ }^{15}$ This is similar to R-square reported in recent research (Ettredge et al. 2006).
} 
Table 5

Future Restatement Probit Model

\begin{tabular}{|c|c|c|c|}
\hline Dependent Variable: $R E S \_F U T$ & B & $\mathbf{z}$ & p-value** \\
\hline CONSTANT & $(1.23)$ & $(4.96)$ & 0.00 \\
\hline$S E G \_M A N$ & 20.34 & 1.70 & 0.09 \\
\hline$E P R$ & 0.00 & 0.82 & 0.41 \\
\hline EPSGROW & $(0.31)$ & $(1.88)$ & 0.06 \\
\hline LOSS & 0.30 & 1.78 & 0.08 \\
\hline$B T M$ & 0.00 & 1.15 & 0.25 \\
\hline$R O A$ & $(1.56)$ & $(2.78)$ & 0.01 \\
\hline$F I N$ & 0.15 & 1.11 & 0.27 \\
\hline FREEC & 1.13 & 2.07 & 0.04 \\
\hline$L E V$ & $(0.05)$ & $(0.22)$ & 0.83 \\
\hline$L T A$ & $(0.00)$ & $(0.13)$ & 0.90 \\
\hline FOREIGN & 0.03 & 0.27 & 0.79 \\
\hline$S E G$ & $(0.01)$ & $(0.18)$ & 0.85 \\
\hline MATWEAK & 0.31 & 2.72 & 0.01 \\
\hline Pseudo R-squared & 0.05 & & \\
\hline $\mathrm{N}$ & 2,415 & & \\
\hline
\end{tabular}

Note: The above model (4) was estimated using a robust logistic model clustered by company as suggested in Peterson (2009). Industry and year controls were included.

**All p-values are two-tailed.

See Table 1 for variable definitions.

\section{CONCLUSION}

This study considers the relationship between audit fees and segment-level manipulation as an appropriate setting to examine an auditor's sensitivity to aggressive financial reporting. Understanding how segment level manipulations are related to audit fees is critically important for at least three reasons: (1) the increasing regulatory emphasis on adequate segment-level disclosures; (2) the attention given to segment disclosures by financial statement users, particularly analysts; and (3) the risk that clients engage in classification management, a type of account manipulation. Our findings have important implications for auditors, investors, and boards. First, auditors need to be attentive to evidence of segment level manipulations. Second, investors need to be aware that despite higher fees and longer audits, managers engage in segment manipulations. Lastly, boards and audit committees need to recognize the potential additional risk their firm faces when managers have the discretion to manipulate segment reporting.

Using a sample of firms that issued internal control reports from 2005 to 2009, we find that audit fees are positively associated with segment level manipulations. This indicates that auditors are either aware of segment manipulations or have uncovered evidence correlated with manipulated segment disclosures, which raises concerns for the auditor. In either case, the auditor prices this risk. To test whether this association is a result of a risk premium or additional work, we examine the association between audit lag and segment-manipulations. We find that the auditor is taking longer to complete the audit for companies engaging in segment manipulation, indicative of the auditor doing additional work. Lastly, we examine whether the elevated fees are justified by examining the association between segment manipulations and future restatements. We find that the likelihood of future restatements is positively associated with segment manipulations which seem to justify the elevated fees.

Our research is subject to some limitations. We have restricted our study to the behavior of Big-N audit firms; therefore, the possibility exists that non-Big $\mathrm{N}$ clients may respond differently to segment-level manipulations as they may have less experience dealing with multi-segment clients. Also, the adoption of the PCAOB Risk Assessment suite in 2010 has made auditors more acutely aware of the risk associated with segment level manipulation, so our results may not generalize to periods following adaption of these standards.

Our research suggests a number of potential future research projects. We have suggested that classificationmanagement is part of an assortment of account management techniques that includes real and accruals management. Future research should consider whether a hierarchy of these earnings management techniques exists 
and whether the prevention of one increases the likelihood managers employ another technique. Finally, researchers should consider how governance elements may influence an auditor's willingness to tolerate classification management.

\section{AUTHORS' INFORMATION}

David Hurtt, Ph.D., received his Ph.D. from Texas A\&M University. He is an Associate Professor at Baylor University. His research interests include audit and financial market behavior. His primarily teaching interest is financial accounting. E-mail: david_hurtt@baylor.edu (Corresponding author)

Bradley E. Lail, CPA, Ph.D., received his Ph.D. from the University of Oklahoma. He is an Assistant Professor at Baylor University in Waco. He is interested in managerial opportunism and account manipulation. His research has appeared in Accounting Horizons and Today's CPA amongst others. E-mail: bradley lail@ baylor.edu

Jason MacGregor, received his Ph.D. from the University of Florida. Since 2007, he has been a member of the Baylor University faculty. His interest is in audit markets. He has been published in Auditing: A Journal of Practice and Theory, Journal of Accounting and Public Policy, Current Issues in Auditing, Journal of Business Ethics, Advances in Taxation, and Accounting Education. E-mail: Jason_MacGregor@baylor.edu

\section{REFERENCES}

1. Abbott, L. J., S. Parker, and G. F. Peters. 2006. Earnings management, litigation risk, and asymmetric audit fee responses. Auditing: A Journal of Practice \& Theory 25: 85-98.

2. Aier, J.K., J. Comprix, M.T. Gunlock, and D. Lee. 2005. The financial expertise of CFOs and accounting restatements. Accounting Horizons 19(3): 123-135.

3. Alfonso, E., D. Hollie, and S.C. Yu. 2012. Managers' Segment Financial Reporting Choice: An Analysis of Firms' Segment Reconciliations. Journal of Applied Business Research 28(6): 1413-1444.

4. Antle, R. and E. Gordon. 2006. The joint determination of audit fees, non-audit fees, and abnormal accruals. Review of Quantitative Finance and Accounting 27: 235-266.

5. Agoglia, C.P., T.S. Doupnik and G.T. Tsakumis. 2011. Principles-Based versus Rules-Based Accounting Standard: The Influence of Standard Precision and Audit Committee Strength on Financial Reporting Decisions. The Accounting Review 86 (3): 747-767.

6. Ashbaugh, H., R. LaFond, and B. Mayhew. 2003. Do non-audit services compromise auditor independence? Further evidence. The Accounting Review 78(3): 611-639.

7. Ashton, R. H., P. R. Graul, and J. D. Newton. 1989. Audit delay and the timeliness of corporate reporting. Contemporary Accounting Research 5(2): 657-673.

8. Baldwin, B. 1984. Segment Earnings Disclosure and the Ability of Security Analysts to Forecast Earnings Per Share. The Accounting Review 59 (3): 376-389.

9. Bedard, J and K. Johnstone. 2004. Earnings Manipulation Risk, Corporate Governance Risk, and Auditor's Planning and Pricing Decisions. The Accounting Review 79 (2): 277-304.

10. Bens. D.A., P.G. Berger and S.J. Monahan. 2011. Discretionary Disclosure in Financial Reporting: An Examination Comparing Internal Firm Data to Externally Reported Segment Data. The Accounting Review 86 (2): 417-449.

11. Berger, P.G. and R. Hann. 2003. The Impact of SFAS 131 on Information and Monitoring. Journal of Accounting Research 41 (2): 163-223.

12. Berger, P.G. and R. Hann. 2007. Segment Profitability and the Proprietary and Agency Costs of Disclosure. The Accounting Review 82 (4): 869-906.

13. Bhattacharya, N., E.L. Black, T.E. Christensen and R.D. Mergenthaler. 2004. Empirical evidence on Recent trends in Pro Forma Reporting. Accounting Horizons 18 (1): 27-43.

14. Blankley, A. I., D. N. Hurtt, and J. E. MacGregor. 2012. Abnormal audit fees and restatements. Auditing: A Journal of Practice and Theory 31, 1 (February): 79-96.

15. Botosan, C. A., and M. Stanford. 2005. Managers' Motives to withhold Segment Disclosures and the Effect of SFAS 131 on Analysts' Information Environment. The Accounting Review 80 (3): 751-771. 
16. Bowlin, Kendall. (2011) Risk-Based Auditing, Strategic Prompts, and Auditor Sensitivity to the Strategic Risk of Fraud. The Accounting Review: July 2011, Vol. 86, No. 4, pp. 1231-1253

17. Bradshaw, M.T. and R.G. Sloan. 2002. GAAP Versus The Street: An Empirical Assessment of Two Alternative Definitions of Earnings. Journal of Accounting Research 40 (1): 41-66.

18. Carslaw, C. A. P. N. and S. E. Kaplan. 1991. An examination of audit delay: Further evidence from New Zealand. Accounting and Business Research 22 (85): 21-32.

19. Chi, W., L. L. Lisic, and M. Pevzner. 2011. Is Enhanced Audit Quality Associated with Greater Real Earnings Management? Accounting Horizons 25, 2 (June): 315-335.

20. Choi, J., J. Kim, and Y. Zang. 2010. Do abnormally high audit fees impair audit quality? Auditing: A Journal of Practice and Theory 29(2): 115-140.

21. Cohen, D. A., A. Dey and T. Lys. 2008. "Real and Accrual-Based Earnings Management in the Pre- and Post-Sarbanes Oxley Periods." The Accounting Review 83(3): 757-787.

22. Collins, D.W. 1976. Predicting earnings with sub-entity data: Some further evidence. Journal of Accounting Research 14: 306-24.

23. DeFond, M. L., K. Raghunandan, and K. R. Subramanyam. 2002. Do nonaudit service fees impair auditor independence? Evidence from going-concern audit opinions. Journal of Accounting Research 40 (September): 1247-1274.

24. Ettredge, M.L.; S.Y. Kwon; D.Smith; and P.Zarowin. 2005. The Impact of SFAS No. 131 Business Segment Data on the Market's Ability to Anticipate Future Earnings. The Accounting Review 80: 773-804.

25. Ettredge, M.L., S.Y. Kwon, D.B. Smith and M.S. Stone. 2006. The Effect of SFAS No. 131 on the CrossSegment Variability of Profits Reported by Multiple Segment Firms. Review of Accounting Studies 17: 91117.

26. Ettredge, M., C. Li, and L. Sun. 2006. The impact of SOX Section 404 internal control quality assessment on audit delay in the SOX Era. Auditing: A Journal of Practice and Theory 25(3): 1-23.

27. Ewert,R. and A. Wagenhofer. 2005. Economic Effects of Tightening Accounting Standards to Restrict Earnings Management. The Accounting Review 80 (October): 1101-1124.

28. Fan, Y., A. Barua, W.M. Cready and W.B. Thomas. 2010. Managing Earnings Using Classification Shifting: Evidence from Quarterly Special Items. The Accounting Review 85 (4): 1303-1323.

29. Fan, Y., and K. Liu. 2012. Reclassifying Core Expenses as Special Items: Cost of Goods Sold or Selling, General, and Administrative Expenses? Working paper, University of Houston.

30. Francis, J. 1984. The effect of audit firm size on audit prices: A study of the Australian market. Journal of Accounting and Economics 6 (August): 133-151.

31. Francis, J. R., and D. Wang. 2005. Impact of the SEC's public fee disclosure requirement on subsequent period fees and implications for market efficiency. Auditing: A Journal of Practice \& Theory 24 (Supplement): 145-160.

32. Frankel, R., M. Johnson, K. Nelson. 2002. The relation between auditors' fees for nonaudit services and earnings management. The Accounting Review 77(Supplement): 71-105.

33. Gendron, Y., J. Bedard, and M. Gosselin. 2004 Getting Inside the Black Box: A Field Study of Practices in "Effective" Audit Committees. Auditing: A Journal of Practice \& Theory: 23 (1): 153-171

34. Ghosh, A., and R. Pawlewicz. 2009. The impact of regulation on audit fees: Evidence from the SarbanesOxley Act. Auditing: A Journal of Practice \& Theory 28 (November): 171-197.

35. Givoly, D., C. Hayn, and J. D’Souza. 1999. Measurement Errors and Information Content of Segment Reporting. Review of Accounting Studies 4: 15-43.

36. Graham, J. R., C. R. Harvey and S. Rajgopal. 2005. "The Economic Implications of Corporate Financial Reporting." Journal of Accounting and Economics 40: 3-73.

37. Gu, Z. and T. Chen. 2004. Analysts' Treatment of Nonrecurring Items in Street Earnings. Journal of Accounting and Economics 38 (Conf.): 129-170.

38. Gul, F., C. Chen, and J. Tsui. 2003. Discretionary accounting accruals, managers' incentives, and audit fees. Contemporary Accounting Research 20: 441-464.

39. Harris, M. 1998. The Association between Competition and Managers' Business Segment Reporting Decisions. Journal of Accounting Research 36: 111-128.

40. Hay, D. C., W. R. Knechel, and N. Wong. 2006. Audit fees: A meta-analysis of the effect of supply and demand attributes. Contemporary Accounting Research 23: 141-191. 
41. Healy, P.M., and Wahlen, J.M. 1999. A Review of the Earnings Management Literature and its Implications for Standard Setting. Accounting Horizons 13 (4): 365-383.

42. Henderson, B. C. and S. E. Kaplan. 2000. An examination of audit report lag for banks: A panel data approach. Auditing: A Journal of Practice and Theory 19, 2(Fall): 159-174.

43. Heninger, W. G. 2001. The association between auditor litigation and abnormal accruals. The Accounting Review 76 (January): 111-126.

44. Johnson, S. 2010. The SEC has a Few Questions for You. CFO Magazine (May).

45. Kinney, W.R. 1971. Predicting earnings: Entity v. sub-entity data. Journal of Accounting Research 9: $112-$ 36.

46. Klein, A. 2002. Economic determinants of audit committee independence. The Accounting Review 77 (2): 435-452.

47. Knechel, W.R. and J. L. Payne. 2001. Additional evidence on audit report lag. Auditing: A Journal of Practice and Theory, 20 (1): 137-146.

48. _ _ and Sharma. 2009. Auditor-provided non-audit services and audit effectiveness and efficiency: Evidence from pre-and post-SOX audit report lags. Working Paper. University of Florida.

49. Krishnan, J. 2005. Did Houston clients of Arthur Andersen recognize publicly available bad news in a timely manner? Contemporary Accounting Research 22 (1): 165-204.

50. Krishnan, J. and J. S. Yang. 2009. Recent trends in audit report and earnings announcement lags. Accounting Horizons, 23(3): 265-288.

51. Lail, B.E., W.B. Thomas and G. Winterbotham. 2013. Strategic Segment Reporting Using the "Corporate/Other" Segment. Accounting Horizons forthcoming.

52. Levitt, A. 1998. Text of speech given on September 28, 1998 at New York University Center for Law and Business.

53. McVay, S. 2006. Earnings Management Using Classification Shifting: An Examination of Core Earnings and Special Items. The Accounting Review 81 (May): 501-531.

54. PCAOB. (2005). Report on 2004 Inspection of Ernst \& Young LLP (104-2005-119). 17\November, $P C A O B$ : Washington, D.C

55. Paul, J. and J. Largay. 2005. Does the management approach contribute to segment reporting transparency?. Business Horizons 48(4): 303-310.

56. Petersen, M.A.. 2009. Estimating standard errors in finance panel data sets: Comparing approaches. Review of Financial Studies, 22(1): 435-480.

57. Richardson, S., I. Tuna, and W. Wu. 2002. Predicting earnings management: The case of earnings restatements. Working paper. University of Pennsylvania.

58. Romanus, R., J. Maher, and D. Fleming. 2008. Auditor industry specialization, auditor changes, and accounting restatements 1997-2006. Accounting Horizons 22(4): 389-413.

59. Roychowdhury, S. 2006. Earnings management through real activities manipulation. Journal of Accounting and Economics 42 (3): 335-370.

60. Schelleman, C. and W.R. Knechel. 2010. Short-term accruals and the pricing and production of audit services. Auditing: A Journal of Practice and Theory, 29 (1): 221 - 250.

61. Sohn, Byungcherl Charlie. Do Auditors Care About Real Earnings Management in their Audit Fee Decisions? (July 31, 2011). Available at SSRN: $\underline{\text { http://ssrn.com/abstract=1899189 }}$ or http://dx.doi.org/10.2139/ssrn.1899189

62. St. Pierre, K. and J. Anderson. 1984. An Analysis of the Factors Associated with Lawsuits Against Public Accountants. The Accounting Review 59(2): 242-263.

63. Stlowy, H. and G. Breton. 2004.Accounts Manipulation: A Literature Review and Proposed Conceptual Framework. Review of Accounting \& Finance 3(1): 5-66.

64. Thomas, W.B. "The Value-relevance of Geographic Segment Earnings Disclosures under SFAS 14." Journal of International Financial Management and Accounting 11 (2000): 133-155.

65. Whisenant, S., S. Sankaragurusuvamy, and K. Raghunandan. 2003. Evidence on the joint determination of audit and non-audit fees. Journal of Accounting Research. 41(4): 721-744. 


\section{$\underline{\text { NOTES }}$}

